\title{
IMAGE SMOOTHING MENGGUNAKAN MEAN FILTERING, MEDIAN FILTERING, MODUS FILTERING DAN GAUSSIAN FILTERING
}

\author{
Bambang Yuwono \\ Jurusan Teknik Informatika UPN "Veteran" Yogyakarta \\ Jl. Babarsari 2 Tambakbayan 55281 Telp (0274) 485323 \\ Email : bambangy@gmail.com
}

\begin{abstract}
Image smoothing aims to suppress the interference (noise) in the image. The disorder usually appears as a result of which is not good penerokan (sensor noise, photographic grain noise) or due to transmission line (the delivery of data) This research has resulted in an application program for image smoothing by four methods: mean filtering, median filtering, Gaussian filtering and filtering modes. Test images used in this study using a sample consisting of twenty 24-bit image and the image of 8 bits. The images are loaded and displayed on the program. Then the image smoothing process was done using the Gaussian method, the mean, median and mode, and displays histogramnya. Parameters measured are the result of image smoothing based on the four methods used, the signal tonoise ratio (SNR), and timing-run.

Keywords : : Image smoothing, mean filtering, median filtering, modus filtering, SNR

Pelembutan Citra (Image smoothing) bertujuan untuk menekan gangguan (noise) pada citra. Gangguan tersebut biasanya muncul sebagai akibat dari hasil penerokan yang tidak bagus (sensor noise, photographic grain noise) atau akibat saluran transmisi (pada pengiriman data)

Penelitian ini telah menghasilkan sebuah program aplikasi untuk image smoothing dengan empat metode yaitu mean filtering, median filtering, modus filtering dan gaussian filtering. Citra uji yang digunakan pada penelitian ini menggunakan duapuluh sampel yang terdiri dari citra 24 bit dan citra 8 bit. Citra tersebut di-load dan ditampilkan pada program. Kemudian dilakuan proses image smoothing dengan menggunakan metode gaussian, mean, median dan modus, serta menampilkan histogramnya. Parameter yang diukur adalah hasil image smoothing berdasarkan keempat metode yang digunakan, signal to-noise ratio (SNR), dan timing-run.

Kata kunci: Image smoothing, mean filtering, median filtering, modus filtering, SNR
\end{abstract}

\section{PENDAHULUAN}

Gangguan pada citra umumnya berupa variasi intensitas suatu pixel yang tidak berkorelasi dengan pixel-pixel tetangganya. Secara visual, gangguan mudah dilihat oleh mata karena tampak berbeda dengan pixel tetangganya. Gambar 1 adalah citra Fox yang mengalami gangguan berupa salt and pepper serta gaussian yang tampil pada gambar dalam bentuk bercak putih atau hitam seperti beras.

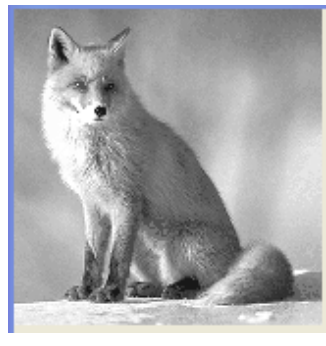

(a)

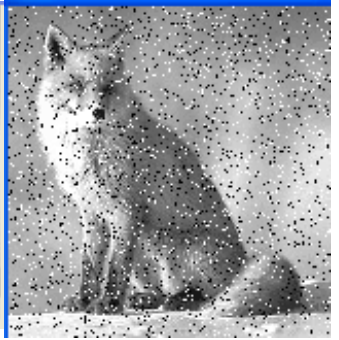

(b)

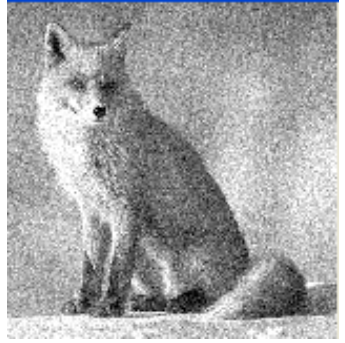

(c)

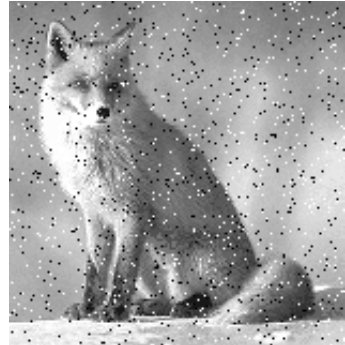

(d)

Gambar 1. Citra Fox yang mengalami gangguan berupa
(a) Asli
(b) Gaussian
(c) salt and pepper
(d) Speckle 
Pixel yang mengalami gangguan umumnya memiliki frekuensi tinggi (berdasarkan analisis frekuensi dengan transformasi Fourier). Komponen citra yang berfrekuensi rendah umumnya mempunyai nilai pixel konstan atau berubah sangat lambat. Operasi pelembutan citra dilakukan untuk menekan komponen yang berfrekuensi tinggi dan meloloskan komponen yang berfrekuensi rendah. Ada beberapa cara atau metode pelembutan citra, diantaranya adalah mean filtering, median filtering, modus filtering dan gausian filtering yang akan dibahas pada tulisan ini.

\section{Tinjauan Pustaka \\ 2.1 Mean Filtering}

Mean adalah nilai rata-rata dari kumpulan data (Usman, 2005).

Rumusan menghitung mean adalah:

$$
\bar{X}=\frac{1}{n} \sum_{i=1}^{n} x_{i}
$$

Keterangan :

$$
\begin{aligned}
& \bar{X}=\text { Nilai rata-rata (Mean) } \\
& \mathrm{n}=\text { Jumlah data } \\
& x_{i}=\text { Nilai ke }-\mathrm{i} \\
& i=\text { Nilai Awal }
\end{aligned}
$$

Mean filtering yang digunakan untuk efek smoothing ini merupakan jenis spatial filtering, yang dalam prosesnya mengikutsertakan piksel-piksel disekitarnya. Piksel yang akan diproses dimasukkan dalam sebuah matrik yang berdimensi $\mathrm{N} X \mathrm{~N}$. Ukuran $\mathrm{N}$ ini tergantung pada kebutuhan, tetapi nilai $\mathrm{N}$ haruslah ganjil sehingga piksel yang diproses dapat diletakkan tepat ditengah matrik. Sebagai contoh matrik berdimensi $3 \times 3$ seperti gambar 2.3 di bawah ini:

\begin{tabular}{|l|l|l|}
\hline 1 & 2 & 3 \\
\hline 4 & $\mathrm{~T}$ & 5 \\
\hline 6 & 7 & 8 \\
\hline
\end{tabular}

\section{Gambar 2.1 Matrik mean filtering}

Nilai 1, 2, 3, 4, 5, 6, 7, dan 8 pada gambar 2.1 adalah piksel-piksel disekitar piksel T yang akan diproses. Nilai 4 didapat dari piksel sebelah kiri dari piksel T, nilai 5 didapat dari piksel di sebelah kanan dari piksel $\mathrm{T}$, proses pengambilan piksel dimulai dengan mengambil piksel yang akan diproses, disimpan dalam nilai T. Kemudian diambil piksel-piksel sekitarnya sehingga matrik terisi penuh. Proses selanjutnya dijumlahkan semua nilai yang terdapat pada matrik tersebut. Hasil penjumlahan tersebut dibagi dengan jumlah titik yang terdapat pada matrik tersebut. Bilangan pembagi ini dapat diperoleh dari perkalian antara N X N. Pada gambar 2.1, maka hasil pembaginya adalah 9 . Sembilan diperoleh dari hasil kali matrik $3 \times 3$. Hasil pembagian tersebut akan menggantikan nilai $\mathrm{T}$. Nilai $\mathrm{T}$ yang baru akan ditampilkan pada layar monitor untuk menggantikan nilai T yang lama.

Proses diatas adalah untuk menggambar grayscale (hitam-putih), untuk menggambar berwarna maka masing-masing titik terlebih dahulu ditentukan nilai warna merah $(R)$, hijau $(G)$, dan biru (B). Masing-masing nilai $R G B$ dijumlahkan. Hasil penjumlahan nilai $R G B$ dibagi dengan jumlah titik yang diproses. Hasil dari pembagian digunakan untuk menentukan warna baru yang akan di letakkan pada titik $\mathrm{T}$.

\section{$2.2 \quad$ Modus Filtering}

Modus adalah nilai variable yang memiliki frekuensi tertinggi (Usman, 2005). Modus dapat ditemukan pada data yang telah diurutkan maupun yang belum terurut. Untuk menentukan modus filter ini, pertama-tama ditentukan piksel utama yang akan diproses dari piksel-piksel disekitarnya. Pada modus filtering digunakan matrik berdimensi N X N. Dari matrik tersebut, kemudian data yang ada diurutkan dan dimasukkan dalam sebuah matrik berukuran $1 \mathrm{X}(\mathrm{N} X \mathrm{~N})$. Hal ini berguna untuk mempermudah menemukan modusnya untuk pencarian nilai yang terbanyak frekuensinya dari kumpulan data yang telah urut tersebut

Sebagai contoh, jika diketahui suatu piksel utama dan piksel-piksel disekitanya adalah: 


\begin{tabular}{|c|c|c|}
\hline 5 & 7 & 2 \\
\hline 7 & 4 & 7 \\
\hline 2 & 7 & 1 \\
\hline
\end{tabular}

Gambar 2.2 Matrik untuk modus filtering

Maka data pada gambar 2.2 harus diurutkan terlebih dahulu sehingga menjadi:

\begin{tabular}{|l|l|l|l|l|l|l|l|l|}
\hline 1 & 2 & 2 & 4 & 5 & 7 & 7 & 7 & 7 \\
\hline
\end{tabular}

Gambar 2.3 Matrik modus filtering setelah diurutkan

Sehingga dari gambar 2.3 dapat diketahui bahwa modus dari matrik tersebut adalah 7 . Nilai 7 akan menggantikan piksel utama yang semula bernilai 4 .

\subsection{Median Filtering}

Median adalah nilai tengah dari kumpulan data (Usman, 2005). Untuk mencari median dari kumpulan data yang ganjil maka:

Keterangan:

$$
x=\frac{n+1}{2}
$$

$$
\begin{aligned}
& \mathrm{n}=\text { Jumlah data } \\
& \mathrm{x}=\text { Nilai baru median }
\end{aligned}
$$

Untuk median filtering ini, data yang digunakan untuk menghitung median terdiri dari kumpulan data yang ganjil. Hal ini disebabkan dengan jumlah data yang ganjil maka piksel yang akan diproses dapat berada ditengah. Pada median filtering digunakan matrik berdimensi $\mathrm{N} \mathrm{X}$ $\mathrm{N}$. Dari matrik tersebut, kemudian data yang ada diurutkan dan dimasukkan dalam sebuah matrik berukuran $1 \mathrm{X}(\mathrm{N} \times \mathrm{N})$. Hal ini berguna untuk mempermudah menemukan median dari kumpulan data yang telah urut tersebut

Sebagai contoh jika diketahui suatu matrik berdimesi $3 X 3$ yang berisi piksel utama dan piksel-piksel disekitarnya :

\begin{tabular}{|l|l|l|}
\hline 9 & 5 & 5 \\
\hline 3 & 8 & 5 \\
\hline 2 & 1 & 4 \\
\hline
\end{tabular}

Gambar 2.4 matrik untuk median filtering

Matrik diatas harus diurutkan terlebih dahulu dan dimasukkan dalam sebuah matrik yang berukuran $1 \mathrm{X}(3 \times 3)$ atau $1 \mathrm{X} 9$.

\begin{tabular}{|l|l|l|l|l|l|l|l|l|}
\hline 1 & 2 & 3 & 4 & 5 & 5 & 5 & 8 & 9 \\
\hline
\end{tabular}

Gambar 2.5 Matrik untuk median filtering setelah diurutkan

Dari gambar 2.5 dapat dicari nilai piksel yang baru dengan menggunakan perhitungan median, maka nilai mediannya adalah $x=5$. Nilai 5 ini akan menggantikan nilai 8 sehingga piksel utamanya akan memiliki warna yang berbeda dengan sebelumnya.

\subsection{Gaussian Filtering}

Gaussian filtering didapat dari operasi konvolusi. Operasi perkalian yang dilakukan ialah perkalian antara matriks kernel dengan matriks gambar asli. Matriks kernel gauss didapat dari fungsi komputasi dari distribusi gaussian, seperti pada persamaan di bawah ini:

$$
G(i, j)=c . e-\frac{(i-u)^{2}+(j-v)^{2}}{2 \sigma^{2}}
$$


Keterangan :

$\mathrm{C}$ dan $\sigma \quad=$ konstanta

$\mathrm{G}(\mathrm{i}, \mathrm{j}) \quad=$ elemen matriks kernel gauss pada posisi $(\mathrm{i}, \mathrm{j})$

$(\mathrm{u}, \mathrm{v}) \quad=$ indeks tengah dari matriks kernel gauss

Berikut ini contoh matrik kernel Gauss $3 \times 3$ dengan $\sigma=1.0$

\begin{tabular}{|l|l|l|}
\hline 1 & 2 & 1 \\
\hline 2 & 3 & 2 \\
\hline 1 & 2 & 1 \\
\hline
\end{tabular}

Gambar 2.6 Matrik kernel gauss $3 X 3$ dengan $\sigma=1.0$

Perkalian antara bobot matriks gambar asli dengan bobot matrik kernel gauss dapat dirumuskan seperti pada di bawah ini:

Pixel B(i,j) $=\frac{1}{K} \cdot \sum_{p=0}^{N-1}\left(\sum_{q=0}^{M-1} G(p, q)\right.$.PixelA $\left.\left.\left(i+p-\frac{(N-1)}{2}, j+q-\frac{(M-1)}{2}\right)\right) \ldots 5\right)$

Keterangan :

Pixel $\mathrm{A}=$ gambar $\mathrm{A}$ (Gambar Asli)

Pixel $B(i, j)=$ bobot hasil perkalian pada posisi $(i, j)$

$\mathrm{N}=$ jumlah kolom matriks kernel

$\mathrm{M}=$ jumlah baris matriks kernel

$\mathrm{K}=$ penjumlahan semua bobot di $\mathrm{G}$

$\mathrm{G}(\mathrm{p}, \mathrm{q})=$ elemen matriks kernel gauss pada posisi $(\mathrm{p}, \mathrm{q})$

Gambar yang akan diproses dibagi menjadi 2 jenis piksel, yaitu piksel batas dan piksel dalam.

Piksel batas yaitu piksel yang berada dipaling luar pada gambar, selain piksel tersebut disebut piksel dalam.

Untuk piksel yang berada di dalam, perkalian dilakukan menggunakan rumus no 5 , yaitu menjadikan piksel yang dicari nilai barunya sebagai piksel tengah dan bobotnya dikalikan dengan bobot pada piksel tengah matrik kernel, lalu dijumlahkan dengan hasil perkalian antara bobot piksel-piksel tetangga-tetangganya dengan bobot piksel matrik kernel. Untuk piksel yang berada disudut atau perbatasan, sebelum dilakukan perkalian, sebelumnya harus mencari bobot pada piksel-piksel luar (dummy). Bobot piksel-piksel ini dicari dengan menggunakan interpolasi yaitu dengan melihat dua piksel di dekatnya yang searah (horizontal atau vertikal). Apabila ada piksel yang memiliki bobot lebih kecil dari 0 maka bobot dijadikan 0 . Apabila ada piksel yang memiliki bobot lebih besar dari 255 maka bobotnya dijadikan 255.

Contoh konvolusi matrik gambar asli(A) dengan matrik kernel gauss $(\mathrm{G})$ :

\begin{tabular}{|l|l|l|l|l|l|l|}
\hline 0 & 5 & 70 & 45 & 0 & 0 & 0 \\
\hline 0 & 20 & 55 & 30 & 10 & 5 & 0 \\
\hline 30 & 35 & 40 & 15 & 60 & 45 & 30 \\
\hline 0 & 15 & 50 & 85 & 23 & 37 & 51 \\
\hline 44 & 52 & 66 & 16 & 33 & 44 & 55 \\
\hline 46 & 47 & 28 & 36 & 7 & 51 & 3 \\
\hline 0 & 62 & 0 & 56 & 0 & 56 & 0 \\
\hline
\end{tabular}

\begin{tabular}{|l|l|l|}
\hline 1 & 2 & 1 \\
\hline 2 & 3 & 2 \\
\hline 1 & 2 & 1 \\
\hline
\end{tabular} G $=$\begin{tabular}{|l|l|l|l|l|}
\hline 390 & 6585 & 510 & 325 & 215 \\
\hline 440 & 570 & 523 & 503 & 483 \\
\hline 529 & 660 & 602 & 579 & 615 \\
\hline 644 & 663 & 556 & 468 & 568 \\
\hline 627 & 468 & 415 & 435 & 649 \\
\hline
\end{tabular}

A

$\mathrm{B}$

\begin{tabular}{|c|c|c|c|c|c|}
\hline \multirow{5}{*}{$\frac{1}{15}$} & 390 & 6585 & 510 & 325 & 215 \\
\hline & 440 & 570 & 523 & 503 & 483 \\
\hline & 529 & 660 & 602 & 579 & 615 \\
\hline & 644 & 663 & 556 & 468 & 568 \\
\hline & 627 & 468 & 415 & 435 & 649 \\
\hline
\end{tabular}

\begin{tabular}{|l|l|l|l|l|}
\hline 26 & 39 & 34 & 22 & 14 \\
\hline 29 & 38 & 35 & 34 & 32 \\
\hline 35 & 44 & 40 & 39 & 47 \\
\hline 43 & 44 & 37 & 31 & 38 \\
\hline 42 & 31 & 28 & 29 & 43 \\
\hline
\end{tabular}

C

Keterangan:

$A=$ Matriks gambar asal $\quad B=$ Matrik hasil perkalian 


\section{$\mathrm{G}=$ Matrik kernel gauss $\quad \mathrm{C}=$ Matrik gambar hasil}

\subsection{Running-time}

Running-time adalah waktu dari awal proses dimulai hingga akhir proses. Waktu mulai dan waktu akhir bekerja secara bersamaan untuk menghitung total waktu yang diperlukan yang ditampilkan dalam satuan detik. Semakin kecil nilai running-time semakin cepat waktu yang digunakan untuk proses, dan semakin besar nilai running-time semakin lama waktu yang digunakan untuk proses (Nalwan,1997). Running-time digunakan untuk mengetahui total waktu yang diperlukan untuk sebuah proses.

\subsection{SNR (signal-to-noise ratio)}

SNR digunakan untuk menentukan kualitas citra setelah dilakukan operasi pengurangan derau. Citra hasil dibandingkan dengan citra asli untuk memberi perkiraan kasar kualitas citra hasil. Semakin besar nilai SNR berarti pengurangan derau dapat meningkatkan kualitas citra, sebaliknya jika nilai SNR semakin kecil maka pada citra hasil hanya sedikit juga peningkatan kualitasnya (Basuki, 2005).

Nilai SNR yang tinggi adalah lebih baik karena berarti rasio sinyal terhadap derau juga tinggi, dimana sinyal adalah citra asli. SNR biasanya diukur dengan satuan decibles (dB).

Rumus untuk menghitung SNR dapat dilihat dalam persamaan berikut:

$$
S N R=10 . \log _{10} \frac{\sum_{m, n} I_{m, n}^{2}}{\sum_{m, n}\left(I_{m, n}-\bar{I}_{m, n}\right)^{2}}
$$

dimana :

$I_{m, n}$ adalah citra asli

$\bar{I}_{m, n}$ adalah citra hasil

$m, n$ adalah ukuran citra

\section{Hasil Dan Pembahasan}

Penelitian ini telah menghasilkan sebuah aplikasi untuk image smoothing dengan menggunakan metode gaussian filtering, mean filtering, median filtering dan modus filtering.

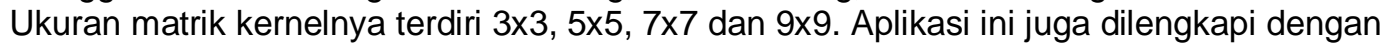
perhitungan SNR dan histogram. Berikut hasil-hasil pengujian programnya.

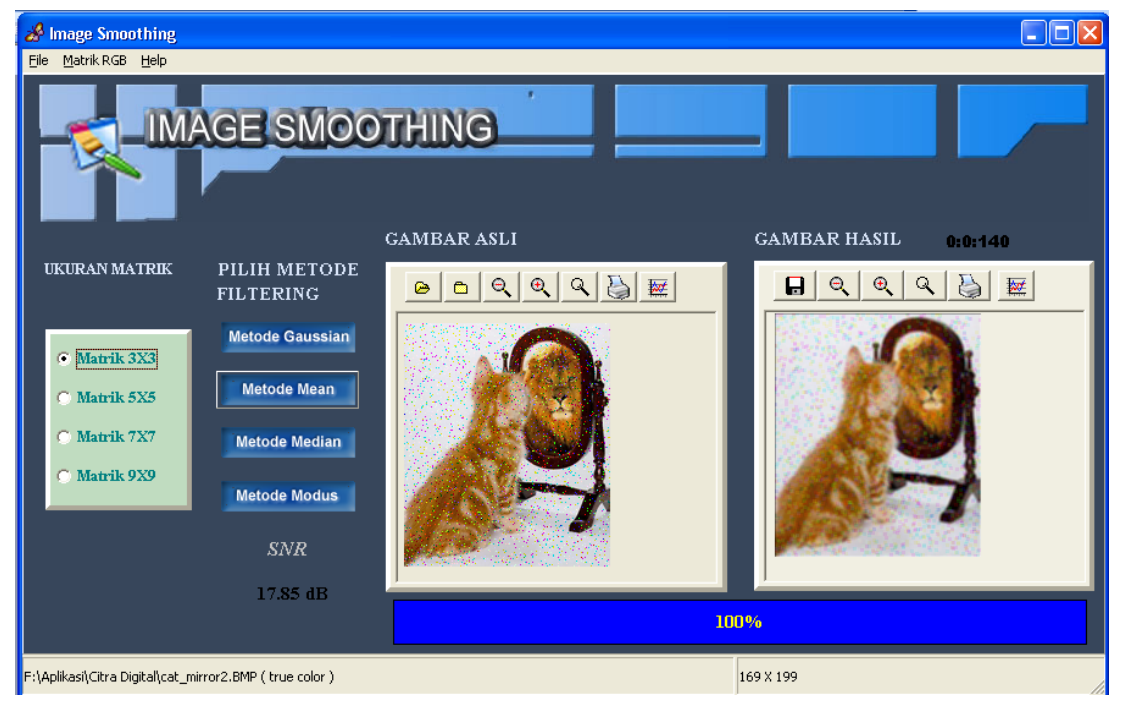

Gambar 3.1 Image Smoothing Menggunakan Metode Mean 


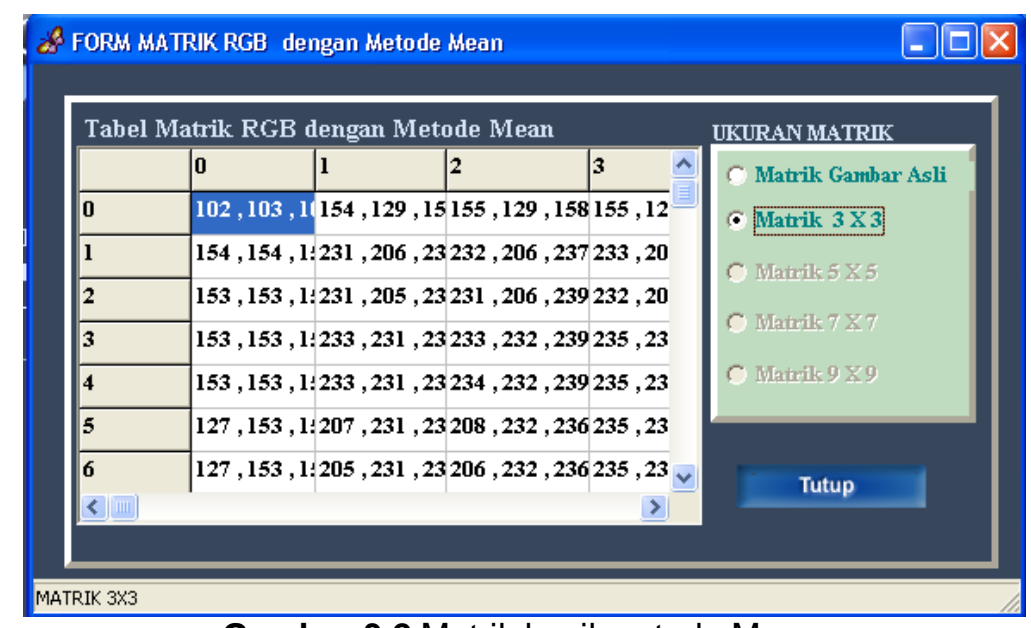

Gambar 3.2 Matrik hasil metode Mean

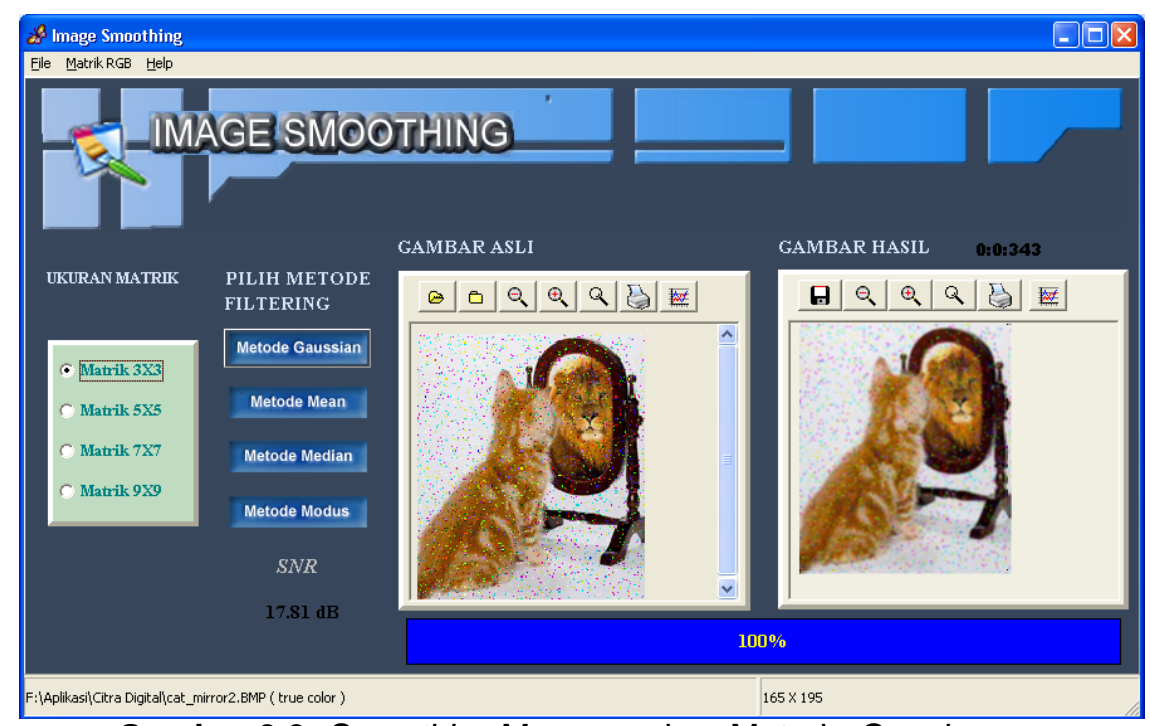

Gambar 3.3 Smoothing Menggunakan Metode Gausian

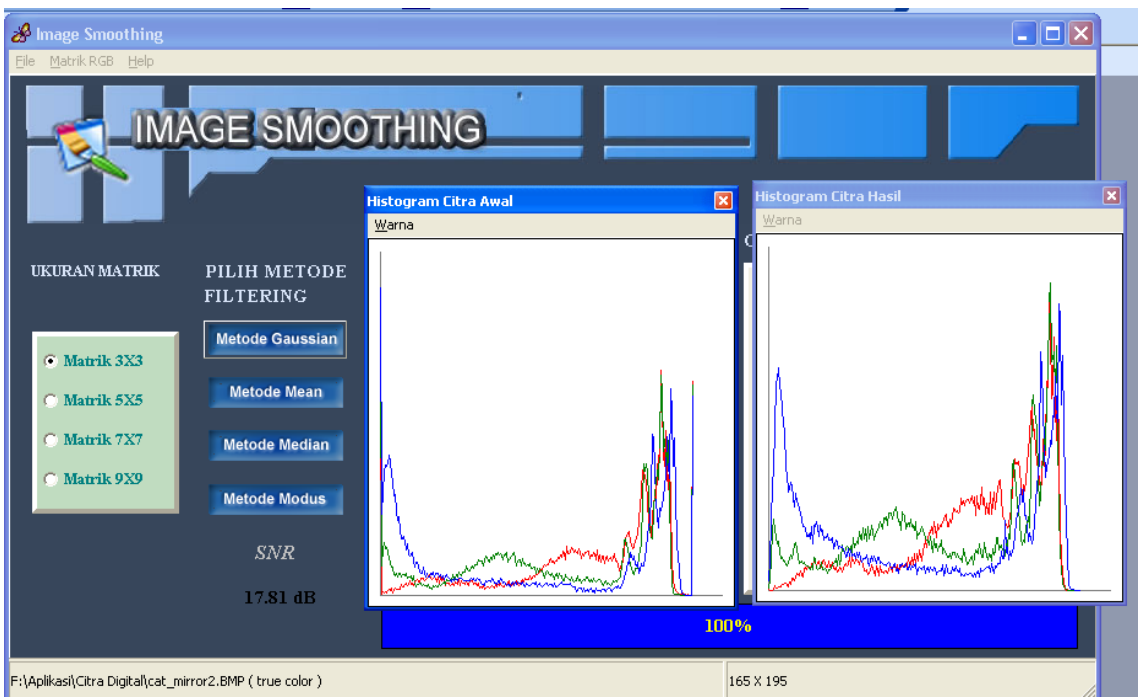

Gambar 3.4 Histogram sebelum dan sesudah smoothing gaussian

\section{Analisis hasil smoothing berdasarkan kualitas gambar}

Dari keempat metode yang digunakan, didapat perbedaan kualitas gambar dari setiap metode yang digunakan. Seperti yang terlihat pada gambar 4.14 berikut ini: 


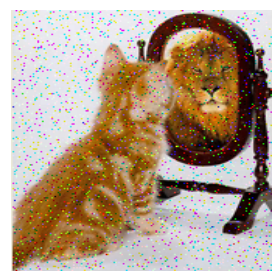

Gambar asli

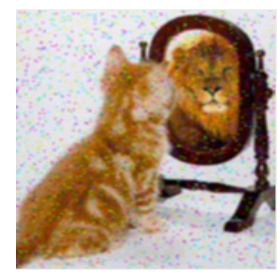

Metode gaussian

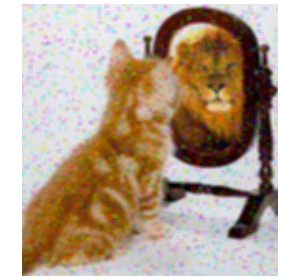

Metode mean

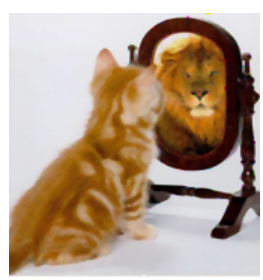

Metode median

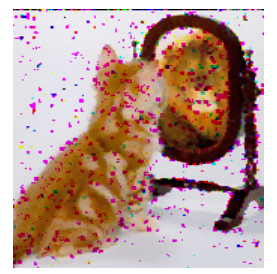

Metode modus

Gambar 3.5 Perbandingan Gambar Berdasarkan Metode Filtering Menggunakan Ukuran Matrik 3 X 3

Dari keempat metode yang digunakan yaitu: Gaussian, Mean, Median, dan Modus didapat gambar yang memiliki kualitas terbaik setelah dilakukan proses smoothing yaitu gambar yang diproses menggunakan metode median. Dengan menggunakan metode median gambar yang diproses akan mengalami penghalusan gambar secara sempurna. Dengan menggunakan metode gaussian, gambar hasil smoothing hampir sama dengan gambar asli yaitu masih memiliki derau meskipun gambar sudah mengalami penghalusan. Dengan menggunakan metode mean gambar hasil smoothing sama dengan gambar hasil metode Gaussian tetapi berubah dari gambar aslinya. Dengan menggunakan metode modus gambar yang dihasilkan memiliki titik-titik noise yang semakin besar.

\section{Analisis hasil smoothing berdasarkan Timing-Run}

Timing-run ini adalah lama waktu proses smoothing pada suatu citra, analisis ini menggunakan duapuluh sampel sehingga didapat hasil yang lebih akurat. Dari keempat metode yang digunakan, didapat selisih waktu untuk melakukan proses smoothing. Seperti yang terlihat pada tabel di bawah ini:

Tabel 3.1 Data Perbandingan Timing-run dari setiap metode filtering Berdasarkan ukuran matrik $3 \times 3$.

\begin{tabular}{|l|l|l|l|l|}
\hline \multicolumn{1}{|c|}{ Nama Citra } & $\begin{array}{l}\text { Waktu } \\
\text { smoothing } \\
\text { dengan metode } \\
\text { gaussian } \\
\text { (detik) }\end{array}$ & $\begin{array}{l}\text { Waktu } \\
\text { smoothing } \\
\text { dengan } \\
\text { metode } \\
\text { mean } \\
\text { (detik) }\end{array}$ & $\begin{array}{l}\text { Waktu } \\
\text { smoothing } \\
\text { dengan metode } \\
\text { median } \\
\text { (detik) }\end{array}$ & $\begin{array}{l}\text { Waktu } \\
\text { smoothing } \\
\text { dengan } \\
\text { metode } \\
\text { modus } \\
\text { (detik) }\end{array}$ \\
\hline Butterfly.bmp 24 bit & 1.883 & 0.591 & 0.861 & 0.982 \\
\hline Kuda.bmp 24 bit & 1.462 & 0.640 & 0.741 & 0.922 \\
\hline Hiu.bmp 24 bit & 1.663 & 0.611 & 1.2 & 0.931 \\
\hline Sun_flower.bmp 24 bit & 1.502 & 0.661 & 0.951 & 0.881 \\
\hline Cat_mirror 24 bit & 1.81 & 0.450 & 0.751 & 0.651 \\
\hline Cow.bmp 8 bit & 1.312 & 0.551 & 0.762 & 0.862 \\
\hline Elephant.bmp 8 bit & 1.923 & 0.620 & 1.101 & 1.82 \\
\hline Fox.bmp 8 bit & 0.881 & 0.430 & 0.511 & 0.671 \\
\hline Nemo.bmp 8 bit & 1.763 & 0.561 & 0.961 & 1.41 \\
\hline Cat_fish 8 bit & 1.61 & 0.581 & 0.711 & 0.781 \\
\hline Bugline_noise.bmp8 bit & 1.763 & 0.601 & 0.862 & 1.1 \\
\hline Goldhiil.bmp 8 bit & 3.896 & 0.931 & 1.522 & 1.802 \\
\hline Penguin.bmp 24 bit & 1.41 & 0.481 & 0.611 & 0.671 \\
\hline Saturn.bmp 24 bit & 1.432 & 0.540 & 0.771 & 0.841 \\
\hline Sphinx.bmp 8 bit & 1.282 & 0.530 & 0.681 & 0.782 \\
\hline Stonehenge.bmp24 bit & 1.533 & 0.551 & 0.781 & 0.852 \\
\hline Freeze.bmp 24.bit & 1.501 & 0.561 & 0.801 & 0.882 \\
\hline Flower.bmp 8 bit & 1.482 & 0.561 & 0.751 & 0.851 \\
\hline Maria.bmp 24 bit & 2.734 & 0.761 & 1.231 & 1.402 \\
\hline
\end{tabular}




\begin{tabular}{|l|c|c|c|c|}
\hline Butterfly.bmp 8 bit & 1.723 & 0.611 & 0.842 & 0.961 \\
\hline
\end{tabular}

Dari data timing-run di atas, dapat dihitung nilai rata-rata dari tiap metode. Dengan menjumlahkan nilai tiap citra dari suatu metode lalu membaginya dengan jumlah sampel citra yang ada, sehingga didapat nilai rata-ratanya yaitu:

Tabel 3.2 Nilai Rata-Rata Timing-run Smoothing

\begin{tabular}{|l|c|}
\hline \multicolumn{1}{|c|}{ Metode Smoothing } & Waktu Proses Rata-Rata (detik) \\
\hline Metode Gaussian & 1.72705 \\
\hline Metode Mean & 0.5912 \\
\hline Metode Median & 0.87015 \\
\hline Metode Modus & 1.0468 \\
\hline
\end{tabular}

Berdasarkan pada tabel di atas maka diperoleh timing-run terbaik dari keempat metode adalah timing-run dengan menggunakan metode mean filtering.

Perbedaan waktu dari keempat proses metode smoothing sangat besar. Data timingrun menunjukkan, proses smoothing dengan menggunakan metode mean membutuhkan waktu lebih cepat dari pada ketiga metode lainnya. Hal ini terjadi karena metode gaussian, median dan modus bekerja dengan mendeteksi dan menghitung terlebih dahulu jumlah frekuensi pemakaian tiap nilai warna yang sama. Apabila terdapat titik yang berada pada range tersebut akan dianggap sebagai noise, yang menyebabkan proses bekerja dua kali lebih lama. Tentu saja hal ini membutuhkan waku yang lebih lama dibandingkan dengan metode mean yang hanya mendeteksi sinyal tinggi dan sinyal rendah nya saja.

\section{Analisis hasil smoothing berdasarkan SNR}

Sama hal nya dengan timing-run di atas, analisis ini juga menggunakan duapuluh sampel yang digunakan dalam uji coba program ini, agar memperoleh hasil yang lebih akurat. SNR dari masing-masing citra uji yang merupakan hasil smoothing dapat dilihat pada tabel di bawah ini.

Tabel 3.3 Perbandingan SNR dari setiap metode filtering berdasarkan ukuran matrik $3 \times 3$.

\begin{tabular}{|l|c|c|c|c|}
\hline \multicolumn{1}{|c|}{ Nama Citra } & $\begin{array}{l}\text { SNR smoothing } \\
\text { dengan metode } \\
\text { gaussian (db) }\end{array}$ & $\begin{array}{l}\text { SNR } \\
\text { smoothing } \\
\text { dengan } \\
\text { metode mean } \\
\text { (db) }\end{array}$ & $\begin{array}{l}\text { SNR } \\
\text { smoothing } \\
\text { dengan } \\
\text { metode } \\
\text { median } \\
\text { (db) }\end{array}$ & $\begin{array}{l}\text { SNR. } \\
\text { smoothing } \\
\text { dengan } \\
\text { metode } \\
\text { modus } \\
\text { (db) }\end{array}$ \\
\hline Butterfly.bmp 24 bit & 18.13 & 17.92 & 17.88 & 16.37 \\
\hline Kuda.bmp 24 bit & 18.05 & 17.82 & 17.78 & 17.48 \\
\hline Hiu.bmp 24 bit & 17.94 & 17.72 & 17.66 & 17.17 \\
\hline Sun_flower.bmp 24 bit & 18.08 & 17.87 & 17.80 & 16.50 \\
\hline Cat_mirror 24 bit & 18.07 & 17.85 & 17.80 & 17.26 \\
\hline Cow.bmp 8 bit & 17.84 & 17.61 & 17.57 & 17.23 \\
\hline Elephant.bmp 8 bit & 18.30 & 18.10 & 18.02 & 17.11 \\
\hline Fox.bmp 8 bit & 18.25 & 18.04 & 17.96 & 17.56 \\
\hline Nemo.bmp 8 bit & 18.21 & 18.00 & 17.94 & 17.48 \\
\hline Cat_fish 8 bit & 18.15 & 17.92 & 17.88 & 17.23 \\
\hline Bugline_noise.bmp 8 bit & 18.22 & 18.02 & 17.93 & 17.56 \\
\hline Goldhiil.bmp 8 bit & 17.97 & 17.77 & 17.70 & 17.36 \\
\hline Penguin.bmp 24 bit & 17.86 & 17.62 & 17.59 & 17.22 \\
\hline Saturn.bmp 24 bit & 17.54 & 17.31 & 17.30 & 16.85 \\
\hline Sphinx.bmp 8 bit & 18.31 & 18.08 & 18.01 & 17.63 \\
\hline Stonehenge.bmp 24 bit & 17.99 & 17.75 & 17.70 & 17.43 \\
\hline Freeze.bmp 24.bit & 17.95 & 17.73 & 17.67 & 17.20 \\
\hline Flower.bmp 8 bit & 18.06 & 17.86 & 17.79 & 17.55 \\
\hline Maria.bmp 24 bit & 18.30 & 18.09 & 18.02 & 17.16 \\
\hline Butterfly.bmp 8 bit & 17.54 & 17.35 & 17.29 & 16.56 \\
\hline
\end{tabular}


Dari data SNR di atas, dapat dihitung nilai rata-rata dari tiap metode. Dengan menjumlahkan nilai tiap citra dari suatu metode lalu membaginya dengan jumlah sampel citra yang ada, sehingga didapat nilai rata-rata nya yaitu:

Tabel 3.4 Nilai Rata-Rata SNR

\begin{tabular}{|l|c|}
\hline \multicolumn{1}{|c|}{ Metode Smoothing } & SNR Proses Rata-Rata $(\mathrm{db})$ \\
\hline Metode Gaussian & 18.038 \\
\hline Metode Mean & 17.8215 \\
\hline Metode Median & 17.766 \\
\hline Metode Modus & 17.1985 \\
\hline
\end{tabular}

Dalam kasus ini nilai rata-rata SNR yang terbaik adalah nilai yang lebih besar, karena nilai SNR didapat dari nilai kualitas citra filter dibandingkan nilai kualitas citra asli yang berderau. Sehingga semakin besar nilai SNR maka semakin rendah ratio sinyal terhadap noise, dimana sinyal adalah citra asli yang berderau. Berdasarkan pada tabel di atas maka diperoleh SNR terbaik dari keempat metode adalah SNR dengan mnggunakan metode gaussian. Besar nilai SNR belum tentu menentukan citra hasil terbaik menurut indra penglihatan.

Dari data yang didapat, SNR citra hasil dibandingkan dengan citra berderau terdapat perbedaan. Perbedaan SNR juga terjadi pada proses smoothing image menggunakan metode gaussian, mean, median dan modus berdasarkan ukuran matrik. Hal ini terjadi karena perbedaan piksel citra uji dan kompleksitas dari gambar, sedangkan keempat metode yang digunakan bekerja pada level piksel.

Proses image smoothing pada metode gaussian, mean, median, modus dengan menggunakan matrik 3 X 3 dan menghasilkan nilai SNR yang besar, hal ini berarti semakin besar peningkatan kualitas citra. Ini disebabkan karena kemungkinan banyak titik noise yang memiliki warna sama pada titik-titik gambar asli, sehingga noise dapat dengan mudah disaring.

\section{Analisis hasil smoothing berdasarkan histogram}

Aplikasi ini menampilkan histogram citra asli dan citra hasil. Dari keempat metode mempunyai banyak kesamaan, yaitu dari lebar histogram yang terdistribusi secara merata keseluruh daerah, baik dari derajat keabuan maupun derajat true-color. Perbedaan terdapat pada daerah tumpukan histogram (gunung dan lembah). Tumpukan histogram antara citra noise sedikit lebih terdistribusi merata. Hal ini terjadi karena intensitas piksel yang dominan merata pada seluruh citra. Dari keempat metode yang digunakan, didapat perbedaan histogram dari setiap metode yang digunakan Seperti terlihat gambar 3.6.

Gambar 3.6 menunjukkan umpukan histogram citra hasil proses smoothing menggunakan metode gaussian, mean, median dan modus terhadap citra noise tidak terdapat perbedaan yang mencolok. Hal ini ditunjukkan dengan tumpukan histogram yang terdistribusi merata keseluruh daerah derajat true-color, namun perbedaan terlihat pada nilai intensitas piksel pada masing-masing metode.

Pada metode gaussian dan metode mean, nilai intensitas piksel pada citra tinggi. Pada metode median nilai intensitas piksel pada citra juga tinggi tetapi memiliki warna yang merata sedangkan pada metode modus histogram terditribusi secara merata keseluruh daerah dengan distribusi yang merata pada setiap nilai intensitas piksel yang berarti tingkat kecerahan gambar tetap terjaga.

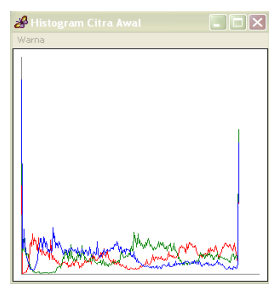

Gambar asli

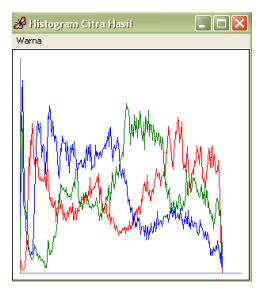

Metode gaussian

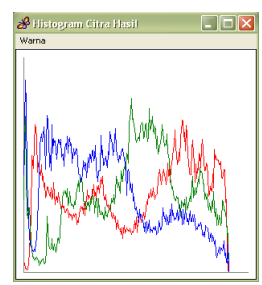

Metode mean

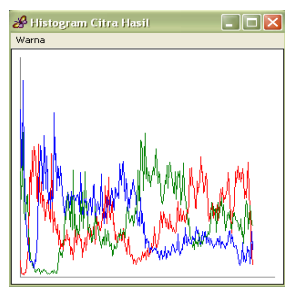

Metode median

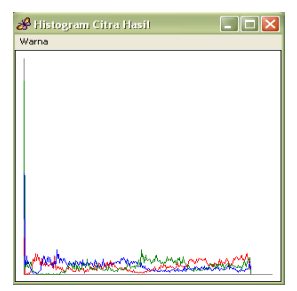

Metode modus

Gambar 3.6 Histogram Citra Kuda2.bmp 24 bit Berdasarkan Metode Filtering Menggunakan Ukuran Matrik 3X3 
Gambar 3.7 menunjukkan tumpukan histogram citra hasil proses smoothing menggunakan metode gaussian, mean, median dan modus terhadap citra noise tidak terdapat perbedaan yang mencolok. Hal ini ditunjukkan dengan tumpukan histogram yang terdistribusi merata keseluruh daerah derajat keabuan dengan distribusi yang merata pada setiap nilai intensitas piksel yang berarti tingkat kecerahan gambar tetap terjaga. Jadi proses smoothing menggunakan metode gaussian, mean, median dan modus pada citra grayscale tidak memberikan pengaruh pada tingkat kecerahan citra ditunjukkan dengan tumpukan histogram yang tetap terdistribusi secara merata.

Perbedaan pada puncak histogram yang nampak terjadi terdapat sewaktu menggunakan metode modus. Pada metode ini puncak histogram lebih rendah dari pada puncak histogram citra asli, ini mengakibatkan nilai intensitas piksel menurun yang mengakibatkan gambar tersebut buram.

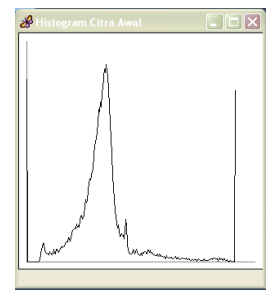

Gambar asli

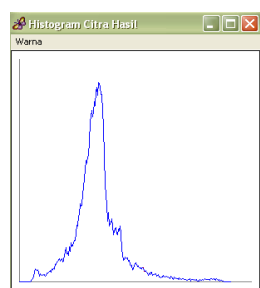

Metode gaussian

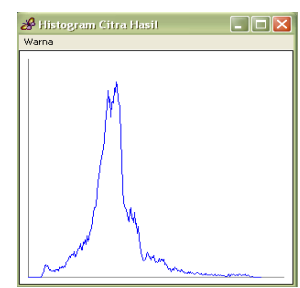

Metode mean

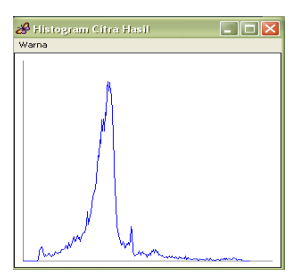

Metode median

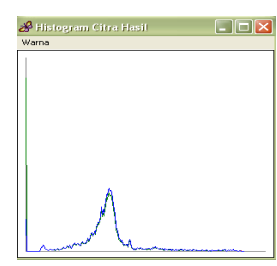

Metode modus

Gambar 4.7 Histogram Citra Cow.bmp 8 bit Berdasarkan Metode Filtering Menggunakan Ukuran Matrik 3X3

\section{Kesimpulan}

Kesimpulan dari hasil penelitian adalah :

1. Secara garis besar timing-run untuk melakukan proses smoothing yang lebih cepat adalah metode mean. Hal ini terjadi karena metode mean hanya mendeteksi intensitas warna piksel pada citra yang meloloskan sinyal tinggi dan sinyal rendah nya saja.

2. Median filtering memberikan hasil yang lebih baik dibandingkan mean filtering untuk citra yang mengalami gangguan dalam bentuk spike berupa bercak-bercak putih maupun dalam bentuk salt and pepper.Bila ukuran mask diperbesar, maka derau semakin banyak dihilangkan, tetapi bersamaan dengan itu informasi detail citra juga ikut dihilangkan sehingga citra nampak kabur Sebaliknya dengan semakin kecilnya ukuran mask, informasi detail citra dapat dipertahankan tetapi derau juga tetap dipertahankan.

3. Berdasarkan pada pengujian maka diperoleh SNR terbaik dari keempat metode adalah SNR dengan menggunakan metode gaussian. Besar nilai SNR belum tentu menentukan citra hasil terbaik menurut indra penglihatan

\section{Daftar Pustaka}

Andeswari. D, 2003, Proses Peningkatan Mutu citra Menggunakan Borland Delphi 5.0, Universitas Ahmad Dahlan, Yogyakarta.

Ansari. T, Filtering and segmentation, www.cse.ohio-state.com, 27-September-2007, 10.00 WIB.

Balza. A dan Firdausy. K, 2005, Teknik Pengolahan Citra Digital, Ardi Publishing,Yogyakarta.

Basuki. A, 2005, Pengolahan Citra Digital Menggunakan Visual Basic, Graha Ilmu, Yogyakarta.

Fitri. A, Perbandingan metode low pass filter dan median filter dalam penghalusan citra untuk meningkatkan kualitas citra, www.digilab.unikom.ac.id, 11-September-2007, 14.30 WIB.

Husni, 2004, Pemrograman Dengan Delphi, Yogyakarta, Penerbit Graha IImu.

Jain. Anil K, 1989, Fundamentals of digital image processing, London, Prenctice-Hall International.

Kiswanto H, Aplikasi Perbandingan Image Smoothing menggunakan empat metode filtering pada pengolahan citra, Informatika UPN, Yogyakarta 
Munir. R, 2002, Algoritma \& Pemrograman, Bandung, Penerbit Informatika.

Munir. R, 2004, Pengolahan Citra Digital dengan Pendekatan Algoritmik, Informatika Bandung, Bandung.

Nalwan. A,1997, Pengolahan Gambar Secara Digital, PT Elex Media Komputindo, Jakarta.

Pranata. Antony, 2001, Pemrograman Borland Delphi. Andi, Yogyakarta.

Perwitasari. E.W, 2006, Analisis Perbandingan Metode Transformasi Wavelet Dengan Metode Contour Untuk Pengurangan Derau Pada Suatu Citra, Universitas Ahmad Dahlan, Yogyakarta.

Smoothing Operation, www.ph.tn.fudelff.nl, 11-September-2007, 15.00 WIB. 